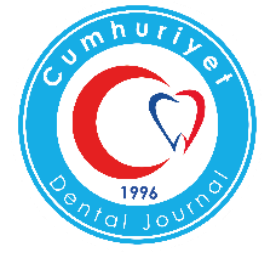

\title{
THE RELATIONSHIP BETWEEN THE SLOPE OF THE MESIOANGULAR LOWER THIRD MOLARS AND THE PRESENCE OF SECOND MOLAR DISTAL CARIES: A RETROSPECTIVE STUDY
}

\author{
Mesioangular Pozisyondaki Mandibular Üçüncü Molar Dişlerin Eğimi ve Komşu \\ İkinci Molar Dişlerin Distal Yüzeyinde Çürük Varlığı Arasındaki Illişki: Retrospektif \\ Bir Çalışma
}

\author{
Ahmet ALTAN $^{1}$, Emrah SOYLU ${ }^{2}$
}

\author{
Makale Kodu/Article Code : :444396 \\ Makale Gönderilme Tarihi $\quad: 16.07 .2018$ \\ Kabul Tarihi \\ : 31.07.2018
}

\section{öz}

Amaç: Bu çalışmanın amacı; mezioangular pozisyondaki mandibular üçüncü molar dişlerin eğimi ile komşu ikinci molar dişlerin distal yüzeyindeki çürük varlığı arasındaki ilişkiyi incelemektir.

Gereç ve Yöntem: Bu retrospektif çalışmada, alt çenede kısmen sürmüş mesioangular pozisyonda gömülü dişi olan, 617 hastanın (328 kadın, 289 erkek) panoramik radyografları incelendi. Mandibular okluzal düzlem ve mandibular üçüncü moların oklüzal yüzeyi arasındaki açı ölçüldü. $11^{\circ}$ ile $30^{\circ}$ arasında bir değere sahip mezioangular üçüncü molar dişler Grup 1 olarak, $31^{\circ}$ ve $50^{\circ}$ arasındakiler Grup 2 olarak, $51^{\circ}$ ve $70^{\circ}$ arasındakiler Grup 3 olarak sınıflandırıldı. Ardından komşu ikinci molar dişin distal temas noktasındaki çürük varlığı tespit edildi.

Bulgular: Mesioangular pozisyonda toplam 816 adet mandibular üçüncü molar diş analiz edildi. Bunlardan 439'u (\%53,8) kadınlarda, 377'si $(\% 46,2)$ erkeklerde görüldü. İkinci molar dişin distalinde çürük prevalans1 erkeklerde \%34,5, kadınlarda \%21,4 idi (p <0,001). Açısal değerlere göre oluşturulan gruplar arasında istatistiksel olarak anlamlı bir fark görüldü $(\mathrm{p}<0,05)$. Sonuçlar, $51^{\circ}$ ile $70^{\circ}$ arasında bir eğime sahip mandibular üçüncü molar dişlerin, ikinci molar dişlerin distal yüzeyinde çürük oluşumu için daha yüksek bir risk arzettiğini gösterdi.

Sonuç: $51^{\circ}$ ile $70^{\circ}$ arasında bir eğime sahip gömülü mandibular üçüncü molar dişlerin profilaktik olarak erken çekimi, komşu ikinci molar dişlerin distal yüzeyinde çürük oluşumunu önleyebilir.

Anahtar Kelimeler: Oral cerrahi, diş çürükleri, üçüncü molar diş

\footnotetext{
${ }^{1}$ Department of Oral and Maxillofacial Surgery, Faculty of Dentistry, Gaziosmanpaşa University, Tokat / Turkey

${ }^{2}$ Department of Oral and Maxillofacial Surgery Faculty of Dentistry, Erciyes University, Kayseri / Turkey
} 


\section{INTRODUCTION}

Teeth that are completely or partially within the bone and soft tissue with no placed in occlusion for various reasons, despite passing the normal eruption age, are called impacted teeth. Impacted teeth may cause various pathologies, such as pericoronitis, infection, unrestorable caries, root resorption in adjacent teeth, periodontal bone loss, cystic lesions, and neoplasms. ${ }^{1}$ The impacted position can be horizontal, vertical, mesioangular, distoangular, buccolingual, or inverted. ${ }^{2}$ Shiller stated that when the angle between the mandibular occlusal plane and the occlusal plane of the third molar is between $11^{\circ}$ and $70^{\circ}$, the tooth position is mesioangular. ${ }^{3}$ Mesioangular and horizontal positions are more frequently associated with pathological conditions. ${ }^{1}$

The teeth with the highest impaction rate are mandibular third molar teeth. ${ }^{4}$ Removal of an impacted third molar is one of the most commonly performed procedures in oral surgery. These teeth are surgically removed for prophylactic, orthodontic, and prosthetic reasons, or for the diagnosis of associated pathologies. The caries formed in the distal part of the second molar teeth justify prophylactic removal of the third molar teeth. McArdle and Renton ${ }^{5}$ reported that distal caries in the second molar will not develop in the absence of the third molar. Furthermore, there is a higher risk of caries formation in the second molar distal associated with partially-erupted mesioangular mandibular third molar teeth. ${ }^{6}$

The purpose of this study was to examine the correlation between the degree of mesioangular mandibular third molar teeth and the presence of distal caries in the second molar teeth by measurements performed on panoramic radiographs.

\section{MATERIALS AND METHODS}

In this retrospective study, panoramic radiographs of 617 patients (328 females, 289 males) with impacted teeth in partially erupted mesioangular position were examined. All patients were transferred to the Department of Oral and Maxillofacial Surgery, Faculty of Dentistry of Gaziosmanpasa University between September 2013 and August 2017. This study included 816 mandibular third molar teeth in the mesioangular position. This study was approved by the local Ethics Committee (Project no: 17KAEK160).

Shiller's method ${ }^{3}$ was used to determine if teeth were in the mesioangular position. According to this method, the angle between the mandibular occlusal plane and the occlusal surface of the mandibular third molar was measured (Figure 1).

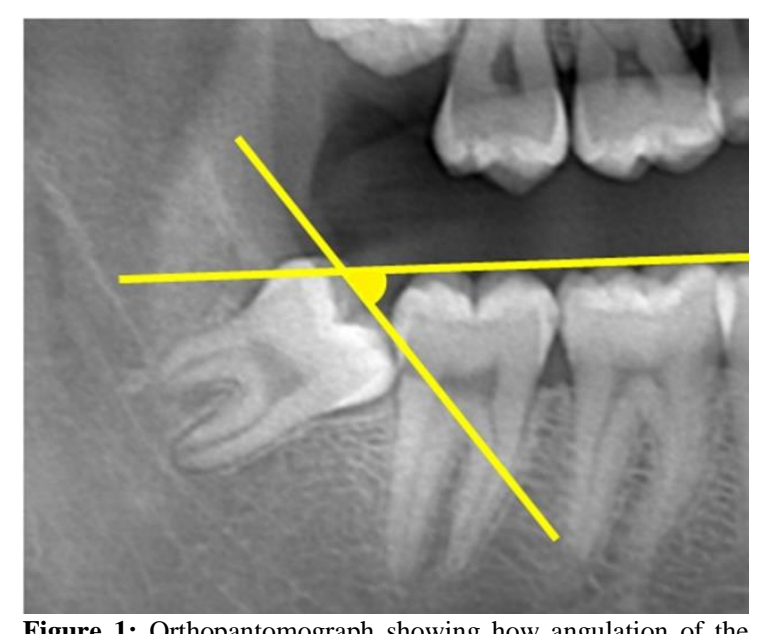

Figure 1: Orthopantomograph showing how angulation of the third molar was measured.

Angular measurements were made using the Image $\mathbf{J}$ software (National Institutes of Health, Bethesda, MD, USA). Values between $11^{\circ}$ and $70^{\circ}$ were determined as being mesioangular positions. The mandibular third molar teeth in mesioangular positions were then categorized into three groups. Third molar teeth with an angle between $11^{\circ}$ and $30^{\circ}$ were classified as Group 1, an angle between $31^{\circ}$ and $50^{\circ}$ as Group 2, and an angle between $51^{\circ}$ and $70^{\circ}$ as Group 3. For each group, the presence of caries in the distal contact point of adjacent second molar teeth was detected from the panoramic radiographs. Patients with preexisting restorations in adjacent second molar teeth were excluded from the study. 
Two of the authors reviewed the panoramic radiographs. Prior to the investigation, calibration of the examiners was undertaken until intra-examiner reliability and reproducibility was achieved. To evaluate intra-examiner agreement, Cohen's Kappa test applied. When those X-rays causing a difference of opinion were analysed by both clinicians together, a consensus was reached by discussion.

IBM SPSS Statistics for Windows, version 20.0 (IBM Corp, Armonk NY, 10504, USA) was used for statistical analyses of the study data. Normality and variance were tested using the one-sample Kolmogorov-Smirnov test. In multiple comparison of measurements of the groups with normal distribution, One-way ANOVA test and Tukey post hoc test were used. When the $p$ value was less than 0.05 , the difference between the variables was considered statistically significant.

\section{RESULTS}

Panoramic radiographs of 617 patients were examined in this study. The age of the patients ranged from 16 to 54 (average: $25.64 \pm 7.03$ ) years. Age and gender distributions are shown in Table 1.

Table 1: Age and gender distribution of patients with mandibular third molar teeth in the mesioangular position

\begin{tabular}{|l|c|c|c|}
\hline Age groups & Female & Male & Total \\
\hline $16-20$ & 101 & 55 & 156 \\
\hline $21-25$ & 135 & 78 & 213 \\
\hline $26-30$ & 45 & 71 & 116 \\
\hline $31-35$ & 30 & 43 & 73 \\
\hline$\geq 36$ & 17 & 42 & 59 \\
\hline Total & 328 & 289 & 617 \\
\hline
\end{tabular}

A total of 816 mandibular third molar teeth in the mesioangular position were analyzed. Of these, $439(53.8 \%)$ were in females and 377 (46.2\%) were in males. The prevalence of caries in the distal aspect of adjacent second molar teeth was $27.5 \%(n=224)$. There was a statistically significant difference between the gender of the patients and the prevalence of caries in the distal second molar teeth $(p<$ $0.001)$. The prevalence of caries in the distal aspect of the second molar teeth was $34.5 \%$ in males and $21.4 \%$ in females (Table 2).

Table 2: Presence of caries on second molar distal aspect associated with gender

\begin{tabular}{|l|c|c|c|}
\hline & \multicolumn{2}{|c|}{$\begin{array}{c}\text { Distal caries in second } \\
\text { molar }\end{array}$} & \\
\hline & Yes & No & Total \\
\hline Female & 94 & 345 & 439 \\
& $(21.4 \%)$ & $(78.6 \%)$ & \\
\hline Male & 130 & 247 & 377 \\
& $(34.5 \%)^{*}$ & $(65.5 \%)$ & \\
\hline Total & 224 & 592 & 816 \\
& $(27.5 \%)$ & $(72.5 \%)$ & \\
\hline${ }^{*} p<0.001$ & \multicolumn{3}{|l}{}
\end{tabular}

A statistically significant difference was found between the groups when the prevalence of caries in the distal aspect of the adjacent second molar teeth was evaluated. Group 3 had the highest ratio of the three groups (Table 3 ).

Tablo 3: Presence of caries in the distal aspect of the second molar teeth

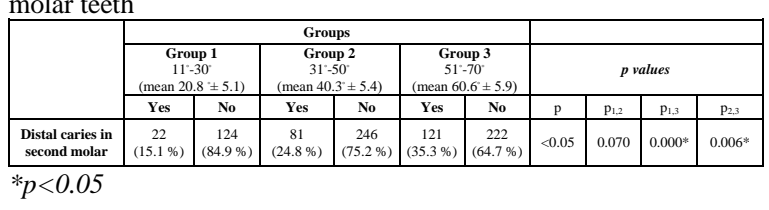

\section{DISCUSSION}

The prophylactic removal of an impacted tooth is defined as the surgical removal of the tooth when there is no pathology or symptom associated with the impacted tooth. The removal of a third molar tooth associated with a pathological condition is usually an easy decision. Some authors advocate prophylactic extraction of impacted third molar teeth due to the possibility of causing pathological conditions, such as caries and periodontal disorder. $^{1,7-9}$ However, some researchers believe there is insufficient evidence to 
prophylactically extract these teeth. ${ }^{10,11}$ Distal caries of mandibular second molar teeth are a common complication associated with impacted third molar teeth. In this study, the relationship between the third molar teeth in the mesioangular position and the presence of caries in the distal aspect of second molar teeth was examined. We found that the prevalence of caries was highest in teeth with a slope between $51^{\circ}$ and $70^{\circ}$.

There is a higher risk of caries formation in the distal aspect of adjacent second molars associated with partially sustained mesioangular mandibular third molar teeth compared with other angulations. ${ }^{6}, 12$ In previous studies, the prevalence of caries formation in the distal aspect of adjacent mandibular second molar teeth has varied between $7 \%$ and $32 \% .^{7-9,} 13$ In this study, the prevalence rate was $27.5 \%$. This range of rates may be related to cultural differences between patients, such as oral hygiene habits, socioeconomic status, and diagnostic methods used. In this study, we believe that the evaluation of the mandibular teeth, in the mesioangular position only, may result in a higher rate.

The relationship between the slopes of the impacted third molar teeth and caries formation in the distal aspect of second molar teeth was examined in this study. Ozec et al. ${ }^{9}$ reported that values of $31^{\circ}$ and $70^{\circ}$ led to a significant risk of second molar distal caries. Falci et al. ${ }^{14}$ reported that when the angulation of mandibular third molar was between $31^{\circ}$ and $108^{\circ}$ there was a greater possibility of distal caries on the second molar. Chang et al. ${ }^{8}$ emphasized that mesial angulation of $41^{\circ}-80^{\circ}$ causes a higher incidence of adjacent second molar caries than in other angulations in the Korean population. The increase of the slope can increase plaque retention and food package on the distal surface of adjacent second molar teeth. In our study, mesioangular values between $11^{\circ}$ and $70^{\circ}$, which were measured according to the Shiller ${ }^{3}$ method, were divided into subgroups. We found the highest caries risk in the distal aspect of second molar teeth between $51^{\circ}$ and $70^{\circ}$ (average: $60.61^{\circ} \pm 5.91$ ) in Turkish population. The results of this study are similar with the literature.

Caries formation in the distal aspect of second molar teeth is a long-lasting process that evolves over time and increases with continued exposure to the oral cavity. It has been reported that the incidence rate of caries in the distal aspect of second molar teeth increases with age. ${ }^{5,} 9,14$ In this study, the prevalence of caries in the distal aspect of second molar teeth was higher in males than in females. We believe this is because of the number of young people between the ages of 16 and 25 was higher among women.

Extraoral radiographs have lower sensitivities than intraoral radiographs in detecting proximal caries. ${ }^{15,16}$ Demineralization is important in the detection of caries by radiography. Panoramic radiography may not detect early caries lesions with inadequate demineralization; however, deep caries lesions that have advanced to the dentine can be detected. Akarslan et al. ${ }^{16}$ reported that when interproximal caries were detected in mandibular molar teeth, there was no significant difference between bitewing and periapical radiographies, but panoramic radiographs were less accurate for this diagnosis. Intraoral radiographs, such as bitewing, are not routinely used in the impacted third molar tooth surgery. In this study, which was conducted with panoramic radiographs of patients with complaints of impacted third molars, the detection of caries by extraoral radiography can be considered a weakness of the study.

\section{CONCLUSIONS}

The results of this study showed that a slope of $51^{\circ}$ to $70^{\circ}$ in mandibular third molar teeth in the mesioangular position presents a higher risk for caries formation in the distal aspect of adjacent second molar teeth. This data will 
help clinicians in making decision on prophylactic extraction of third molar teeth without symptoms. Early prophylactic extraction of impacted mandibular teeth with a slope between $51^{\circ}$ and $70^{\circ}$ may prevent caries formation in the distal aspect of adjacent second molar teeth.

\section{REFERENCES}

1. Polat HB, Ozan F, Kara I, Ozdemir H, Ay

S. Prevalence of commonly found pathoses associated with mandibular impacted third molars based on panoramic radiographs in Turkish population. Oral Surg Oral Med Oral Pathol Oral Radiol Endod 2008; 105, e41-47.

2. Gaddipati R, Ramisetty S, Vura N, Kanduri RR, Gunda VK. Impacted mandibular third molars and their influence on mandibular angle and condyle fractures-a retrospective study. J Craniomaxillofac Surg 2014; 42, 1102-1105.

3. Shiller WR. Positional changes in mesioangular impacted mandibular third molars during a year. J Am Dent Assoc 1979; 99,460464.

4. Damlar İ, Altan A, Tatlı U, Arpağ OF. Retrospective Investigation of the Prevalence of Impacted Teeth in Hatay. Cukurova Med Journal 2014; 39, 559-565.

5. McArdle LW, Renton TF. Distal cervical caries in the mandibular second molar: an indication for the prophylactic removal of the third molar? Br J Oral Maxillofac Surg 2006; 44, 42-45.

6. Pepper T, Grimshaw P, Konarzewski T, Combes J. Retrospective analysis of the prevalence and incidence of caries in the distal surface of mandibular second molars in British military personnel. Br J Oral Maxillofac Surg 55, 2017; 160-163.

7. Chu FC, Li TK, Lui VK, Newsome PR, Chow RL, Cheung LK. Prevalence of impacted teeth and associated pathologies--a radiographic study of the Hong Kong Chinese population. Hong Kong Med J 2003; 9, 158163.
8. Chang SW, Shin SY, Kum KY, Hong J. Correlation study between distal caries in the mandibular second molar and the eruption status of the mandibular third molar in the Korean population. Oral Surg Oral Med Oral Pathol Oral Radiol Endod 2009; 108, 838-843.

9. Ozec I, Herguner Siso S, Tasdemir U, Ezirganli S, Goktolga G. Prevalence and factors affecting the formation of second molar distal caries in a Turkish population. Int J Oral Maxillofac Surg 2009; 38, 1279-1282.

10.Song F, Landes DP, Glenny AM, Sheldon TA. Prophylactic removal of impacted third molars: an assessment of published reviews. $\mathrm{Br}$ Dent J 1997; 182, 339-346.

11.Adeyemo WL. Do pathologies associated with impacted lower third molars justify prophylactic removal? A critical review of the literature. Oral Surg Oral Med Oral Pathol Oral Radiol Endod 2006; 102, 448-452.

12. Srivastava N, Shetty A, Goswami RD, Apparaju V, Bagga V, Kale S. Incidence of distal caries in mandibular second molars due to impacted third molars: Nonintervention strategy of asymptomatic third molars causes harm? A retrospective study. Int J Appl Basic Med Res 2017; 7, 15-19.

13.van der Linden $W$, Cleaton-Jones $P$, Lownie M. Diseases and lesions associated with third molars. Review of 1001 cases. Oral Surg Oral Med Oral Pathol Oral Radiol Endod 1995; 79, 142-145.

14.Falci SG, de Castro CR, Santos RC, de Souza Lima LD, Ramos-Jorge ML, Botelho AM et al. Association between the presence of a partially erupted mandibular third molar and the existence of caries in the distal of the second molars. Int J Oral Maxillofac Surg 2012; 41, 1270-1274.

15. Clark HC, Curzon ME. A prospective comparison between findings from a clinical examination and results of bitewing and panoramic radiographs for dental caries diagnosis in children. Eur J Paediatr Dent 2004; 5, 203-209. 
The Relationship Between the Slope of The Mesioangular Lower Third Molars and the Presence of Second Molar Distal Caries: A Retrospective Study

16. Akarslan ZZ, Akdevelioglu M, Gungor K, Erten H. A comparison of the diagnostic accuracy of bitewing, periapical, unfiltered and filtered digital panoramic images for approximal caries detection in posterior teeth. Dentomaxillofac Radiol 2008; 37, 458-463.

\section{Corresponding Author}

Ahmet ALTAN

Gaziosmanpasa University,

Ali Sevki EREK Yerleskesi,

Tokat / TURKEY

Tel $\quad$ : +905057013189

Fax : +903562124225

E-mail : dt.ahmetaltan@gmail.com 